MEDICAL SCIENCE IN THE WAR.

SIR ANTHONY BOWLBY, at the annual general meeting of the Research Defence Society on June 26, gave an admirable little address on "Experimental Medicine and the Sick and Wounded in the War." He spoke with authority; there is no surgeon with more right to do that. But, of course, he could not do more than touch points here and there of the great subject. He took for these points typhoid, tetanu., gas-gangrene, dysentery, and trench-fever, and he began with this praise of our Army: that it had been the healthiest Army in the war, partly because "the average Briton is naturally a cleanly animal," partly because the British soldier understands a reasonable explanation, and is guided by it in daily life, and partly because our Army Medical Service, "a body of men unequalled in any other country on the face of the globe," was constantly lecturing to the combatant officers, who in their turn instructed their men in the ways of health. So it came to pass that the amount of "sick wastage" in our Army was kept low; and that is how the war was won.

If that were all, or anything like all, there would be some excuse for the foolish people who say that the health of our Army was safeguarded, not by experimental medicine, but by "ordinary sanitation." But, as Sir Anthony said, "the hygiene of to-day is based upon the experimental medicine of yesterday." It was hygiene to protect our men against typhoid and our wounded men against tetanus; but it came out of the experimental work of Nicolaier, Wright, and others; there was no possible way but that, if it was ever to come. He reminded his hearers of the vivid contrast early in the war between the British Expeditionary Force and the French Army; how France, to save herself, had to send out her Army unprotected against typhoid; there was no time to protect them; "the result was that between August $x$ and April they had as many as 60,000 cases of enteric." He might have added the not less remarkable results of the protective treatment later in the war against paratyphoid.

Next, Sir Anthony spoke of tetanus. We all remember how, in the first months of the war, our national anxiety for our men was heightened by the dreadful news that there was a great deal of tetanus among the wounded:- "At the beginning of the war in France we had a truly terrible attack of tetanus among our wounded. Everybody was surprised and alarmed. The prevalence of the disease had not been anticipated, and consequently there was no prophylactic serum in proportion to the number of troops. We could not suddenly supply them with preventive doses of serum. It had to be made. We obtained all the supplies we could get from America, but it took time. In August, September, and October, I9r4, our troops were to a great extent uninoculated, and the result was an appalling amount of tetanus. Shortly afterwards almost every man was able to be inoculated. The ratio of the number of cases of tetanus to the number of wounded was about six times as high in September, I9I4, as it was in November, and nine times as high as it was in December of the same year."

Sir Anthony spoke also of experimental medicine in relation to the study and treatment of gas-gangrene and of dysentery, and he and Capt. Walter Elliot (who seconded a vote of thanks to him) spoke of trench-fever and of those memorable experiments on self, by British and American volunteers, which proved the transmission of trench-fever by lice, and made it possible to bring down "by leaps and bounds" the evil done by the disease. Strange to think, with these facts before us, that there are so many people who still belong to "anti-vivisection" societies.

\section{EXPERIMENTAL STUDIES OF} SELECTION.

$M$ R. A. STURTEVANT has experimented (Publication 264 , Carnegie Institution of Washington, I9.8, pp. I-68, I plate) with a mutant race of the fruit-fly, Drosophila melanogaster (ampelophila), with the particular object of determining the effects of selection. The mutant character in question is known as Dichæt; it appeared in $\mathrm{I}_{9} \mathrm{I}_{5}$ in a single female which had wings extended and bent backwards near the base, and with only two dorso-central bristles instead of the usual four. This "Dichæt" character behaves as a dominant, and it appears that the factor or gene corresponding with it is located "in the third chromosome, approximately five units to the left of pink." Dichæt-flies are more variable in bristlenumber than are non-Dichæets. The variability is partly environmental, partly genetic.

Selection is generally admitted to be capable of effecting change, either gradually or sudienly, in the mean character of a mixed race, but if this be granted a number of questions arise. Does selection use germinal differences that are already present, or differences that arise during the experiment? To this the author answers that selection produces its effects chiefly through isolation of factors already present, though occasionally available mutations do arise in the course of the experiment. But if selection uses new differences, does it cause them to occur more frequently, and does it influence their direction? To this the author answers that there are no available data warranting an affirmative answer.

What selection does is to isolate genetic differences already present. The experiments made on the Dichæt-fly go to show that genes are relatively stable, not being contaminated in heterozygotes, and mutating only very rarely. There is strong confirmation of the multiple-factor view that characters may be influenced by more than one pair of genes. There are genes that modify other genes, but there is no experimental evidence that allelomorphs present in the heterozygote may influence or "contaminate" each other, so that they do not come out unchanged. The general outcome of Mr. Sturtevant's elaborate investigation is to lead us to believe that the chief role of selection is in isolating favourable combinations of genes.

\section{FUNGUS DISEASES OF ECONOMIC PLANTS.}

TTO A. REINKING (Philippine Journal of Science, vol. xiii., section A, July, 19 I8) supplies a list of fungus diseases of Philippine economic plants which will be of value to plant-growers in other tropical areas. The warmth and moisture of the climate account for the great number and destructiveness of these diseases during the wetter months of the year, and Mr. Reinking estimates that in the province in which he is specially interested at least ro per cent. of agricultural crops are destroyed by fungi. The great factors in the spread and destructiveness of fungi are the lack of proper culture, of sanitation, of pruning, and of spraying. Many of the plants concerned are widely cultivated in the tropics, and the paper has been written in order to give some idea of the prevalence of plant diseases, their causes, mode of attack, plant hosts, the amount of damage, and also the methods of control. Many of the diseases are due to fungus species new to science. The account is illustrated by twenty-two plates and fortythree text-figures.

Under the title "Seedling Diseases of Conifers" (Journal of Agricultural Research, Washington, D.C., NO. 2592 , VOL. IO3] 